\title{
EFFECTS PRODUCED BY THE INTRAVENOUS INJECTION IN MAN OF A TOXIC ANTIGENIC MATERIAL DERIVED FROM EBERTHELLA TYPHOSA: CLINICAL, HEMATOLOGICAL, CHEMICAL AND SEROLOGICAL STUDIES
}

\author{
By GRANT O. FAVORITE AND HERBERT R. MORGAN 1 \\ (From the Department of Preventive Medicine and Public Health, Hahnemann Medical College, \\ Philadelphia, and the Department of Bacteriology and Immunology, Harvard \\ Medical School and School of Public Health, Boston)
}

(Received for publication May 4, 1942)

The preparation of purified antigenic materials from cultures of Eberthella typhosa $(1,2)$ has demonstrated that substances of relative purity, and high antigenic and toxic activity, may be isolated for study. In investigations utilizing a synthetic medium for the culture of E. typhosa (3), which eliminates the possibility of non-specific contaminating materials (derived from the culture medium), a toxic, antigenic material has been isolated which has been extensively studied. This material acts as a complete antigen, giving rise to the formation of agglutinins (4), precipitins (4), bactericidal antibodies (5), and mouse-protective antibody (6). Possessing marked toxicity, it kills mice, rabbits, and guinea pigs with relatively small doses (4). A study of the tissues obtained from animals receiving intravascular injections of the material has shown pathological changes involving the heart muscle, lung, liver, spleen, bone marrow, and vascular bed (7). On intravenous injection in rabbits, the material induces a pronounced leukopenia and a marked temperature rise (4). Because of these properties it was desired to determine, insofar as possible, whether the material might exhibit similar effects following intravenous injection into patients for the purpose of inducing therapeutic febrile reactions.

\section{MATERIALS AND METHODS}

\section{Preparation of antigen}

Following the technique previously described $(3,4)$ involving repeated precipitations with alcohol and resuspension in water, an antigenic material was obtained from cultures of $E$. typhosa grown in a liquid medium which consisted only of ingredients removable by dialysis (3). The material which contained the $\mathrm{O}$ and $\mathrm{Vi}$ antigens possessed all the properties exhibited by that previously studied (4). The stock solution of antigen was made up

1 John Ware Memorial Student Research Fellow. in distilled water and stored in the refrigerator for over a year. During this time no loss of activity was observed. From this stock solution containing $1 \mathrm{mgm}$. per cc. of the antigen, successive dilutions were prepared in physiologic saline for intravenous administration.

\section{Methods of administration}

The patients selected for this study represented 11 cases of asymptomatic neurosyphilis, and 1 normal person. The group included 7 males and 5 females. The injections were administered intravenously into the median basilic vein. Observations on temperature, pulse, and respiration were recorded at hourly intervals.

\section{$\therefore \quad$ Hematological determinations}

At hourly intervals after the injections, total and differential leukocyte counts were made on capillary blood obtained from a finger. At certain intervals, erythrocyte counts and hemoglobin (Sahli) determinations were carried out. On several patients, repeated determinations of the sedimentation rate were made, using $15 \mathrm{cc}$. of blood to which was added 0.2 cc. of 20 per cent potassium oxalate. This blood was placed in a Cutler tube and the rate of sedimentation recorded. The tube was then placed in the centrifuge and spun at 2500 r.p.m. for 45 minutes. The volume of packed cells was then measured with calipers and expressed as a percentage of the total volume in the tube.

\section{Chemical determinations}

Hourly measurements of certain constituents of the blood were made following the administration of various amounts of the antigen, using oxalated blood prepared by adding $0.2 \mathrm{cc}$. of 20 per cent potassium oxalate to $15 \mathrm{cc}$. of blood. Total proteins were determined by the falling drop method (8), urea nitrogen determinations were obtained by the method of Karr (9), and creatinine by the technique of Folin and Wu (10). Blood glucose values were obtained using the method of Folin and Wu (11), chlorides by that of Whitehorn (12), and the carbon dioxide combining power of the plasma by the technique of Van Slyke and Cullen (13). Throughout the 12 hours of experiment, the patients received only water. 


\section{Agglutinins}

At certain periods, serum was obtained from the patients just before the subsequent injection, and its titer of antibody measured by agglutination, precipitation and bactericidal tests. Alcohol treated bacterial suspensions of E. typhosa strain 0901, and serial dilutions of the serum in a macroscopic test, were used to measure the titer of 0 agglutinins. $H$ agglutinins were assayed by means of a suspension of the H901 strain of E. typhosa to which 0.2 per cent formalin was added. A rough strain of $E$. typhosa containing the $\mathrm{Vi}$ antigen was used in a saline suspension to test for the presence of $\mathrm{Vi}$ agglutinins. These tests were read after incubation for 2 hours at $37^{\circ} \mathrm{C}$. and after remaining overnight in the refrigerator. The titers were recorded as the highest dilution producing $a+++$ reaction in a series graded from + to ++++ .

\section{Precipitins}

These tests were carried out by the ring technic. Undiluted serum was placed in a series of tubes over which were layered dilutions of the antigen in saline. The tests were read after 1 hour at room temperature (20 to $24^{\circ}$ C.).

\section{Bactericidal antibodies}

The determinations of bactericidal antibody were made by means of a technique previously described (5) in which measured amounts of the serum dilutions, diluted broth culture of the strain of E. typhosa from which the antigen was prepared, and $0.25 \mathrm{cc}$. of diluted guinea pig serum were added to a series of small Pyrex glass tubes. After these tubes were sealed in an oxygen-gas flame, they were placed at $37^{\circ} \mathrm{C}$. in a rotating device which turned at the rate of 7 to 8 revolutions per hour. Twentyfour hours later the contents of the tubes were distributed over the surfaces of infusion agar plates, which were then incubated at $37^{\circ} \mathrm{C}$. for 48 hours. The titer was taken as the highest dilution which killed all of the organisms added to the tube. In each experiment, suitable controls were included to reveal any inhibition of bacterial growth alone attributable to the antiserum or the diluted guinea pig serum. For each patient, the bactericidal tests performed 'on the 2 serum samples were carried out simultaneously to avoid differences due to variations in the materials used, i.e., complement and bacterial culture.

\section{EXPERIMENTAL}

\section{Determination of the effective dose and subsequent rejections}

Because previous experiments with animals had shown that the antigen was toxic in very small amounts (4), the small initial dose of $0.0001 \mathrm{mgm}$. of antigen in $1 \mathrm{cc}$. of saline was administered. Following this injection, a rise in rectal temperature to levels varying from 100.2 to $101.8^{\circ} \mathrm{F}$. oc-
TABLE I

Temperature and agglutinin response to initial and subsequent antigen injections

\begin{tabular}{|c|c|c|c|c|}
\hline Patient & Date & Dose & $\begin{array}{l}\text { Maximum } \\
\text { tempera- } \\
\text { ture- } \\
\text { rectal }\end{array}$ & $\begin{array}{l}0 \text { agglu- } \\
\text { tinin titer } \\
\text { dilution } \\
\text { of serum }\end{array}$ \\
\hline 1 & January 28, 1941 & $\begin{array}{c}m g m . \\
0.0001\end{array}$ & $100.2^{\circ} \mathrm{F}$ & \\
\hline 2 & $\begin{array}{l}\text { October } 15,1940 \\
\text { October 22, } 1940 \\
\text { October 23, } 1940 \\
\text { October 25, } 1940 \\
\text { October 26, } 1940 \\
\text { October 28, } 1940 \\
\text { October 29, } 1940\end{array}$ & $\begin{array}{l}0.0001 \\
0.004 \\
0.01 \\
0.01 \\
0.01 \\
0.01 \\
0.01\end{array}$ & $\begin{array}{l}100.2 \\
101.8 \\
104.4 \\
102.4 \\
102 \\
102.2 \\
101.4\end{array}$ & $1: 8192$ \\
\hline 3 & $\begin{array}{l}\text { December } 9,1940 \\
\text { December 20, } 1940 \\
\text { December 23, } 1940 \\
\text { December 26, } 1940 \\
\text { December 27, } 1940\end{array}$ & $\begin{array}{l}0.0001 \\
0.05 \\
0.1 \\
0.1 \\
0.1\end{array}$ & $\begin{array}{l}100.6 \\
103.8 \\
106.6 \\
103 \\
102.6\end{array}$ & $\begin{array}{l}1: 16 \\
1: 32 \\
1: 256 \\
1: 256 \\
1: 512\end{array}$ \\
\hline 4 & $\begin{array}{l}\text { November } 6,1940 \\
\text { November } 15,1940 \\
\text { November } 17,1940 \\
\text { November } 19,1940 \\
\text { November 21, } 1940 \\
\text { November } 23,1940\end{array}$ & $\begin{array}{l}0.0001 \\
0.04 \\
0.1 \\
0.1 \\
0.3 \\
0.3\end{array}$ & $\begin{array}{l}101.6 \\
103.4 \\
105.2 \\
104.4 \\
105.8 \\
104.6\end{array}$ & $\begin{array}{c}0 \\
1: 4096 \\
1: 8192 \\
1: 4096\end{array}$ \\
\hline 5 & February 4, 1941 & 0.0002 & 100.2 & $1: 20$ \\
\hline 6 & $\begin{array}{l}\text { November } 25,1940 \\
\text { November 26, } 1940 \\
\text { November 28, } 1940 \\
\text { November 30, } 1940 \\
\text { December 3, } 1940 \\
\text { December 6, } 1940 \\
\text { March 7, 1941 } \\
\text { October 17, } 1941 \\
\text { January } 28,1942\end{array}$ & $\begin{array}{l}0.0002 \\
0.001 \\
0.005 \\
0.01 \\
0.05 \\
0.1 \\
0.01 \\
0.03 \\
0.05\end{array}$ & $\begin{array}{l}100.4 \\
103.0 \\
103.2 \\
104.2 \\
101.4 \\
102.6 \\
102.8 \\
103 \\
105\end{array}$ & $\begin{array}{l}1: 8 \\
1: 128 \\
1: 2048 \\
1: 8192 \\
1: 512\end{array}$ \\
\hline 7 & $\begin{array}{l}\text { June } 18,1941 \\
\text { June } 20,1941 \\
\text { June } 23,1941 \\
\text { June } 25,1941 \\
\text { July } 1,1941 \\
\text { July } 3,1941\end{array}$ & $\begin{array}{l}0.0002 \\
0.02 \\
0.02 \\
0.1 \\
0.5 \\
0.5\end{array}$ & $\begin{array}{l}101 \\
105 \\
103 \\
102.4 \\
105.2 \\
101.6\end{array}$ & $\begin{aligned} & 0 \\
& 0 \\
1 & : 512 \\
1 & : 2048 \\
1: & 2048 \\
1: & 4096\end{aligned}$ \\
\hline 8 & April 17, 1941 & 0.0002 & 101.8 & 0 \\
\hline 9 & June 25, 1941 & 0.0005 & 101.2 & $1: 8$ \\
\hline 10 & November 3, 1940 & 0.001 & 102.6 & 0 \\
\hline 11 & January 22,1941 & 0.001 & 101 & $\mathbf{0}$ \\
\hline
\end{tabular}

curred. Doubling this dose on the following injection caused a rise to values of $100.2^{\circ}$ to $101.8^{\circ}$ $\mathrm{F}$. One patient was given $0.005 \mathrm{mgm}$. and 2 were given $0.01 \mathrm{mgm}$. as the initial dose (Table I). The temperatures rose to $101^{\circ} \mathrm{F}$. and $102.6^{\circ} \mathrm{F}$., respectively.

From this data it is evident that an initial dose of less than $0.001 \mathrm{mgm}$. proved quite safe and that the systemic reactions which occurred were not 
disturbing. After several injections, in each of which the dosage was doubled, it became possible to increase subsequent doses fivefold without causing severe reactions. An interval of at least one day was allowed between each injection. Some patients became capable of tolerating as much as
$0.5 \mathrm{mgm}$. in a single injection, following gradual increase of dosage over a period of several weeks. This increase proved necessary to obtain adequate febrile responses, because the patients developed a tolerance to the antigen after repeated injections of amounts which previously had been

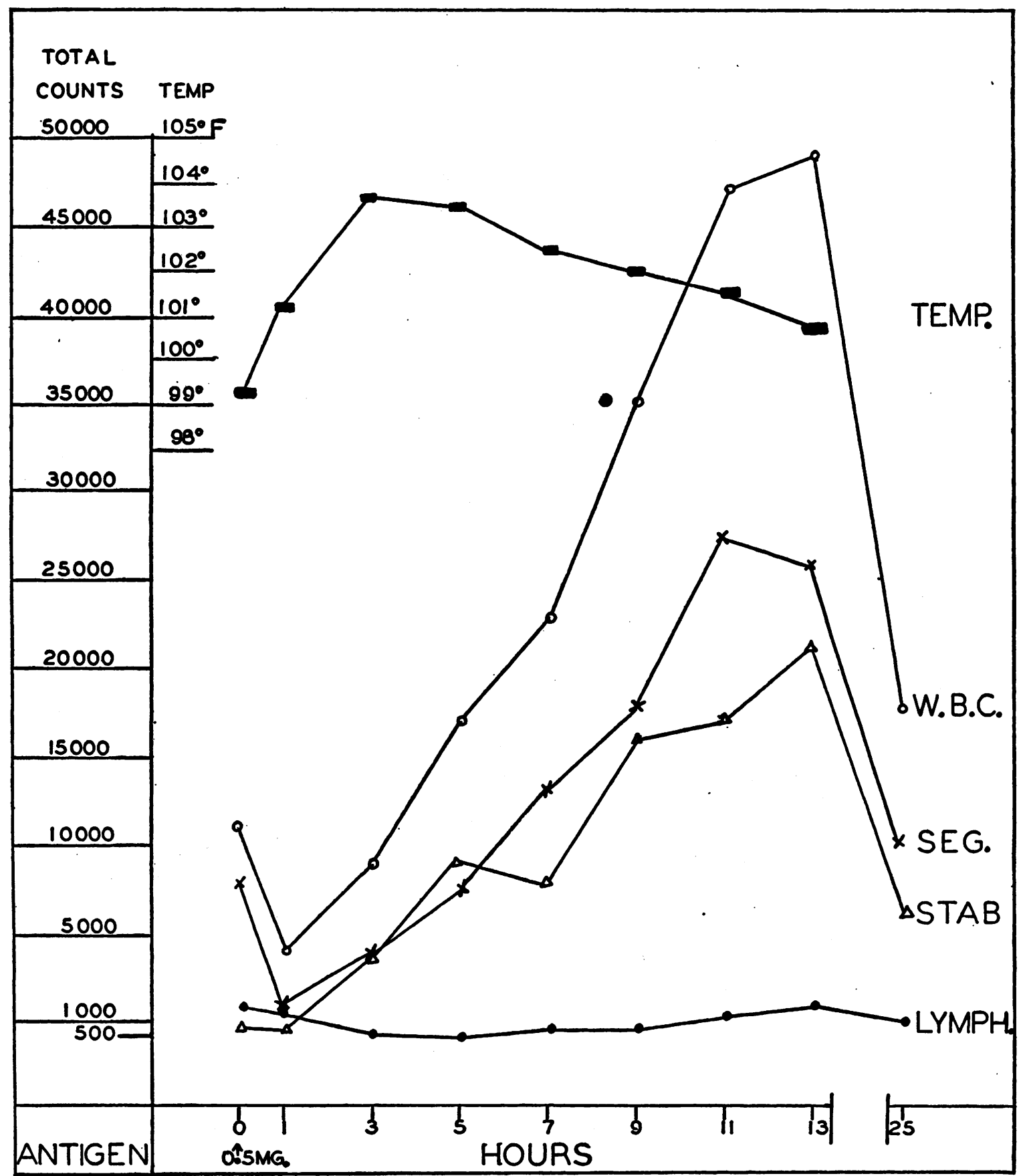

Fig. 1. Typical Febrile and Leukocyte Responses Following Injection of Antigen 
TABLE II

Changes in leukocyte count following injection of antigen

Patient 8

\begin{tabular}{|c|c|c|c|c|c|c|c|c|c|}
\hline \multirow{2}{*}{ Date } & \multirow{2}{*}{ Dose } & \multirow{2}{*}{\multicolumn{4}{|c|}{$\begin{array}{l}\text { Leukocyte count at hourly intervals } \\
\text { following injection }\end{array}$}} & \multicolumn{2}{|c|}{$\underset{\text { count }}{\text { Maximum leukocyte }}$} & \multicolumn{2}{|c|}{$\begin{array}{l}\text { Restoration to normal } \\
\text { leukocyte count }\end{array}$} \\
\hline & & & & & & & $\begin{array}{l}\text { Time } \\
\text { after injection }\end{array}$ & & $\begin{array}{c}\text { Time } \\
\text { after injection }\end{array}$ \\
\hline $\begin{array}{l}\text { April 17, } 1941 \\
\text { April 18, } 1941 \\
\text { April 23, } 1941 \\
\text { April 25, } 1941 \\
\text { April 30, } 1941 \\
\text { May 2, 1941 }\end{array}$ & $\begin{array}{l}m g m . \\
0.0002 \\
0.0006 \\
0.001 \\
0.006 \\
0.03 \\
0.03\end{array}$ & $\begin{array}{c}0 \\
7200 \\
4200 \\
5400 \\
4800 \\
6000 \\
7200\end{array}$ & $\begin{array}{c}1^{p e} \\
4200 \\
2000 \\
2200 \\
2200\end{array}$ & $\begin{array}{c}2 \\
4000 \\
2600 \\
\\
6600 \\
7000 \\
3600\end{array}$ & $\begin{array}{c}3 \\
4400 \\
7600 \\
\\
7200 \\
6800 \\
8000\end{array}$ & $\begin{array}{c}\text { per } m m .8 \\
\\
13500 \\
15000 \\
10500 \\
20500 \\
37500 \\
32000\end{array}$ & $\begin{array}{c}\text { hours } \\
6 \\
6 \\
7 \\
4.5 \\
10 \\
12 \\
8 .\end{array}$ & $\begin{array}{r}\text { per mm. } \\
\\
8000 \\
8000 \\
9500 \\
5600 \\
10000 \\
10400\end{array}$ & $\begin{array}{l}\text { hours } \\
\\
12.5 \\
14 \\
6.5 \\
24 \\
28 \\
24\end{array}$ \\
\hline
\end{tabular}

adequate. The data in Table I illustrate this decreasing response which was particularly striking in patients 3 and 7 . Tolerance developed upon repeated injections regardless of the increase of the amount administered in a single injection. The data on patient 6 indicates, however, that the refractory state was maintained only by continued injections. The reactions to reinjection at considerable intervals of time in this patient also suggest that the antibody titer is not closely correlated with this resistant state, since the titer remained considerable at a time when the patient developed febrile reactions of $103^{\circ}$ and $105^{\circ} \mathrm{F}$, following injections (Table I).

\section{Systemic reactions following injections}

When an effective dose was administered, the symptoms elicited were quite uniform. Within 30 to 40 minutes following the injection, the patient experienced a chilly sensation which culminated in a definite rigor of varying intensity which lasted from 25 to 35 minutes. This was followed by generalized aching sensations, which at times were accompanied by localization of pain in some part of the body such as the head, legs, or back. Nausea and occasional vomiting also accompanied these symptoms. Within the first hour, the temperature rose above $100^{\circ} \mathrm{F}$., reaching its fastigium in 2 to 3 hours and falling to $100^{\circ} \mathrm{F}$., or less, within 7 to 8 hours. The pulse and respiration showed a corresponding rise. A typical temperature curve is presented in Figure 1.

Perspiration made its appearance during the height of the fever and continued for 2 or 3 hours.
This was followed by a feeling of fatigue, exhaustion and a diminution in the intensity of the other symptoms.

\section{Alterations in the cellular components of the blood following injection}

a. Total leukocyte counts. The total leukocyte count followed a characteristic pattern in part dependent on the amount of antigen administered. With an effective dose, a definite fall in the leukocyte count occurred during the first 2 hours. The degree of leukopenia was proportional to the amount of antigen injected. Again with repeated injections, as in the case of the febrile reaction, larger amounts of antigen were required to produce a leukopenia of the same degree. A representative protocol is presented in Table II.

Following the leukopenia, a gradual increase in the number of leukocytes occurred until the count returned to its normal level after 3 to 4 hours. Subsequently, a leukocytosis was observed within 9 to 12 hours (Figure 1). The count then decreased until the normal level was again reached. The time required for the development of leukocytosis and subsequent return to the normal state appeared to be proportional to the dosage. Total white counts of 30,000 per mm. ${ }^{3}$, or higher, were not uncommon, and some values as high as 67,000 per $\mathrm{mm}^{3}$ were obtained. When such pronounced leukocytosis occurred, the return to a normal level required a longer time interval (Table II).

b. Differential leukocyte counts. The cellular responses described were largely due to changes in the numbers of polymorphonuclear leukocytes, 
especially the stab and segmented forms. An occasional metamyelocyte was seen.

During the first hour after the injection, usually the period of leukopenia, the stab cells showed a slight increase, with a subsequent sharp rise during the second hour to a level 2 to 4 times that of the first hour (Table III and Figure 1). This level was maintained and was even increased as long as the leukocytosis persisted, with a return towards the original level as the total leukocyte count fell to normal values. If the patient had received a series of consecutive injections, the stab cell count was high originally and tended to remain above its initial level, even though the total leukocyte count was approaching pre-injection values, as is shown in the case of patient 7 (Table III). With the larger doses of antigen, the reaction was accompanied with a more marked leukocytosis and a correspondingly higher stab cell count.

The segmented cells showed a definite decrease during the first hour which was roughly proportional to the degree of leukopenia (Figure 1).
This was followed by an hourly increase which more or less paralleled the total leukocyte count, with the highest values for segmented cells being attained in 8 to 15 hours during the height of the leukocytosis. The restitution to normal levels was more rapid than that in the case of the stab cells, but was influenced by the same factors.

Both stab and segmented forms revealed toxic granulation of the cytoplasm which was more marked with larger amounts of the antigen. The preponderance of the stab cells was similar to that seen in the blood picture of patients with typhoid fever (14).

During the first hour (leukopenic phase) there was little change in the number of lymphocytes, with a resultant relative increase; this was in marked contrast to the changes described in the numbers of stab and segmented leukocytes. However, there was a sudden decrease between the 3rd to 6 th hours with a subsequent gradual increase reaching normal or somewhat greater values during the phase of leukocytosis as seen in Table III and Figure 1.

TABLE III

Differential leukocytic count. Changes in metamyelocytes, stab cells, segmented cells and lymphocytes

\begin{tabular}{|c|c|c|c|c|c|c|c|c|c|}
\hline \multirow{2}{*}{ Hours } & \multirow{2}{*}{$\begin{array}{l}\text { Total white } \\
\text { count }\end{array}$} & \multicolumn{2}{|c|}{ Metamyelocytes } & \multicolumn{2}{|c|}{ Stab cells } & \multicolumn{2}{|c|}{ Segmented cells } & \multicolumn{2}{|c|}{ Lymphocytes } \\
\hline & & & Number & & Number & & Number & & Number \\
\hline $\begin{array}{c}\text { Patient } 1 \\
0\end{array}$ & $\begin{array}{c}\text { per } m m .^{3} \\
6500\end{array}$ & per cent & per $m m$. & $\begin{array}{c}\text { per cent } \\
6\end{array}$ & $\begin{array}{c}\text { per } m m .^{2} \\
390 .\end{array}$ & $\begin{array}{c}\text { per cent } \\
43\end{array}$ & $\begin{array}{c}\text { per } m m .8 \\
2795\end{array}$ & $\begin{array}{c}\text { per cent } \\
49\end{array}$ & $\begin{array}{c}\text { per } m m . \\
3185\end{array}$ \\
\hline $\begin{array}{r}1 \\
2 \\
3 \\
4 \\
5 \\
6 \\
7 \\
9 \\
11 \\
13 \\
15 \\
28 \\
30\end{array}$ & $\begin{array}{r}5600 \\
7900 \\
6300 \\
7900 \\
8200 \\
9900 \\
13700 \\
25500 \\
27600 \\
24900 \\
21400 \\
11500 \\
9800\end{array}$ & 1 & 79 & $\begin{array}{l}13 \\
37 \\
47 \\
37 \\
34 \\
42 \\
30 \\
39 \\
10 \\
13 \\
11 \\
5 \\
8\end{array}$ & $\begin{array}{c}\text { gm. antig } \\
728 \\
2923 \\
2961 \\
2923 \\
2788 \\
4158 \\
4110 \\
9945 \\
2760 \\
3237 \\
2354 \\
550 \\
784\end{array}$ & $\begin{array}{l}\text { ntray } \\
33 \\
48 \\
41 \\
56 \\
58 \\
52 \\
61 \\
54 \\
78 \\
76 \\
69 \\
77 \\
65\end{array}$ & $\begin{array}{r}\text { usly } \\
1848 \\
3792 \\
2583 \\
4424 \\
4756 \\
5148 \\
8357 \\
13770 \\
21528 \\
18924 \\
14766 \\
8470 \\
6370\end{array}$ & $\begin{array}{r}54 \\
14 \\
12 \\
6 \\
8 \\
6 \\
8 \\
6 \\
12 \\
11 \\
20 \\
18 \\
27\end{array}$ & $\begin{array}{r}3024 \\
1106 \\
756 \\
474 \\
656 \\
594 \\
1096 \\
1530 \\
3312 \\
2739 \\
4280 \\
1980 \\
2646\end{array}$ \\
\hline $\begin{array}{c}\text { Patient } 7 \\
0\end{array}$ & 5400 & & & 22 & 1188 & 47 & 2538 & 27 & 1458 \\
\hline $\begin{array}{r}2 \\
4 \\
6 \\
8 \\
12 \\
14 \\
24 \\
30 \\
35\end{array}$ & $\begin{array}{r}6400 \\
11800 \\
11000 \\
24800 \\
29800 \\
28100 \\
10700 \\
10700 \\
13800\end{array}$ & $\begin{array}{l}1 \\
4 \\
1 \\
1\end{array}$ & $\begin{array}{r}118 \\
440 \\
298 \\
107\end{array}$ & $\begin{array}{l}0.1 \\
39 \\
48 \\
40 \\
49 \\
55 \\
45 \\
47 \\
36 \\
33\end{array}$ & $\begin{array}{c}\text { gm. antiø } \\
2496 \\
5664 \\
4400 \\
12152 \\
16390 \\
12645 \\
5029 \\
3852 \\
4554\end{array}$ & $\begin{array}{l}\text { ntrave } \\
39 \\
39 \\
53 \\
44 \\
35 \\
31 \\
37 \\
35 \\
50\end{array}$ & $\begin{array}{r}\text { usly } \\
2496 \\
4602 \\
5830 \\
10912 \\
10430 \\
8711 \\
3959 \\
3745 \\
6900\end{array}$ & $\begin{array}{r}17 \\
12 \\
3 \\
7 \\
8 \\
21 \\
13 \\
23 \\
17\end{array}$ & $\begin{array}{r}1008 \\
1416 \\
330 \\
1736 \\
2384 \\
5901 \\
1391 \\
2461 \\
2346\end{array}$ \\
\hline
\end{tabular}


TABLE IV

Sedimentation rate following the injection of the antigen

\begin{tabular}{|c|c|c|c|c|c|c|c|c|c|c|c|}
\hline \multirow{2}{*}{ Patient } & \multirow{2}{*}{ Date } & \multirow{2}{*}{ Dose } & \multirow{2}{*}{$\begin{array}{c}\text { Injection } \\
\text { number }\end{array}$} & \multicolumn{8}{|c|}{ Sedimentation rate of blood drawn at hourly intervals } \\
\hline & & & & $\mathbf{0}$ & 1 & 2 & 3 & 4 & 5 & 6 & 7 \\
\hline & & $m g m$. & & \multicolumn{8}{|c|}{ mm. per hour } \\
\hline 1 & $\begin{array}{l}\text { February } 11,1941 \\
\text { February } 18,1941 \\
\text { February } 25,1941\end{array}$ & $\begin{array}{l}0.12 \\
0.5 \\
0.6\end{array}$ & $\begin{array}{r}7 \\
9 \\
11\end{array}$ & $\begin{array}{l}19 \\
23 \\
26.5\end{array}$ & $\begin{array}{l}19.5 \\
25 \\
28\end{array}$ & $\begin{array}{l}20 \\
23 \\
29\end{array}$ & $\begin{array}{l}18 \\
22 \\
27.5\end{array}$ & $\begin{array}{l}20.5 \\
22.5 \\
28\end{array}$ & $\begin{array}{l}20 \\
24 \\
27\end{array}$ & $\begin{array}{l}20 \\
23.5 \\
26\end{array}$ & $\begin{array}{l}21 \\
19.5 \\
28\end{array}$ \\
\hline 7 & $\begin{array}{l}\text { June 20, } 1941 \\
\text { July } 1,1941\end{array}$ & $\begin{array}{l}0.02 \\
0.5\end{array}$ & $\begin{array}{l}3 \\
6\end{array}$ & $\begin{array}{l}21 \\
21\end{array}$ & $\begin{array}{l}18 \\
21\end{array}$ & $\begin{array}{l}17.5 \\
18\end{array}$ & $\begin{array}{l}16.5 \\
19\end{array}$ & $\begin{array}{l}17.5 \\
17\end{array}$ & $\begin{array}{l}17.5 \\
17\end{array}$ & $\begin{array}{l}18.5 \\
16\end{array}$ & $\begin{array}{l}18 \\
18\end{array}$ \\
\hline 12 & $\begin{array}{l}\text { January 22, } 1942 \\
\text { January 24, } 1942 \\
\text { January 27, } 1942 \\
\text { February 2, } 1942 \\
\text { February } 13,1942\end{array}$ & $\begin{array}{l}0 \\
0.001 \\
0.01 \\
0.2 \\
0.8\end{array}$ & $\begin{array}{r}0 \\
1 \\
2 \\
3 \\
10\end{array}$ & $\begin{array}{l}2.0 \\
15 \\
17 \\
15 \\
15\end{array}$ & & & & & & & - \\
\hline
\end{tabular}

The monocytes and basophiles showed no outstanding changes. Eosinophiles were constantly absent during the phase of the leukocytosis.
To check the determinations, simultaneous leukocyte counts were made on blood obtained from the finger and oxalated blood obtained from

TABLE V

Fasting blood glucose, chlorides, and carbon dioxide combining power of the plasma, following the administration of antigen

\begin{tabular}{|c|c|c|c|c|c|c|c|c|c|c|}
\hline \multirow[t]{2}{*}{ Patient } & \multirow[t]{2}{*}{ Date } & \multirow[t]{2}{*}{ Antigen } & \multicolumn{8}{|c|}{ Glucose at hourly intervals } \\
\hline & & & $\mathbf{0}$ & 1 & 2 & 3 & 4 & 5 & 6 & 7 \\
\hline \multirow[t]{2}{*}{1} & $\begin{array}{l}\text { February } 11,1941 \\
\text { February 18, } 1941 \\
\text { February 25, } 1941 \\
\text { June 20, 1941 } \\
\text { July 1, 1941 } \\
\text { April 25, 1941 } \\
\text { April 30, 1941 } \\
\text { July 18, 1941 }\end{array}$ & $\begin{array}{l}\text { mgm. } \\
0.12 \\
0.5 \\
0.6 \\
0.02 \\
0.5 \\
0.006 \\
0.03 \\
0.1\end{array}$ & $\begin{array}{r}90 \\
100 \\
100 \\
95 \\
86 \\
90 \\
95 \\
80\end{array}$ & $\begin{array}{l}83 \\
83 \\
80 \\
80 \\
73 \\
86 \\
80 \\
77\end{array}$ & $\begin{array}{l}90 \\
95 \\
83 \\
68 \\
36 \\
95 \\
95 \\
68\end{array}$ & $\begin{array}{r}\text { per } \\
95 \\
95 \\
86 \\
83 \\
36 \\
111 \\
111 \\
68\end{array}$ & $\begin{array}{c}\text { c. of blo } \\
95 \\
100 \\
100 \\
90 \\
34 \\
118 \\
111 \\
80\end{array}$ & $\begin{array}{r}95 \\
95 \\
100 \\
100 \\
40 \\
118 \\
118 \\
77\end{array}$ & $\begin{array}{r}95 \\
95 \\
133 \\
100 \\
50 \\
125 \\
111 \\
77\end{array}$ & $\begin{array}{r}100 \\
95 \\
100 \\
111 \\
60 \\
118 \\
111 \\
100\end{array}$ \\
\hline & & & \multicolumn{8}{|c|}{ Sodium chloride } \\
\hline \multirow[t]{2}{*}{1} & $\begin{array}{l}\text { February } 11,1941 \\
\text { February } 18,1941 \\
\text { February 25, } 1941 \\
\text { June 20, 1941 } \\
\text { July 1, 1941 } \\
\text { April 18, 1941 } \\
\text { April 25, 1941 } \\
\text { April } 30,1941 \\
\text { July } 18,1941\end{array}$ & $\begin{array}{l}0.12 \\
0.5 \\
0.6 \\
0.02 \\
0.5 \\
0.0006 \\
0.006 \\
0.03 \\
0.1\end{array}$ & $\begin{array}{l}492 \\
484 \\
528 \\
528 \\
495 \\
493 \\
560 \\
560 \\
478\end{array}$ & $\begin{array}{l}463 \\
474 \\
462 \\
495 \\
412 \\
435 \\
495 \\
511 \\
495\end{array}$ & $\begin{array}{l}454 \\
412 \\
462 \\
495 \\
472 \\
464 \\
528 \\
528 \\
478\end{array}$ & $\begin{array}{c}\text { mer } \\
471 \\
446 \\
462 \\
544 \\
511 \\
551 \\
478 \\
495 \\
462\end{array}$ & $\begin{array}{l}\text { c. of blo } \\
500 \\
480 \\
363 \\
511 \\
462 \\
435 \\
511 \\
495 \\
445\end{array}$ & $\begin{array}{l}394 \\
480 \\
412 \\
478 \\
445 \\
450 \\
495 \\
495 \\
462\end{array}$ & $\begin{array}{l}437 \\
446 \\
\\
478 \\
445 \\
435 \\
495 \\
495 \\
462\end{array}$ & $\begin{array}{l}496 \\
428 \\
445 \\
495 \\
495 \\
449 \\
495 \\
478 \\
429\end{array}$ \\
\hline & & & \multicolumn{8}{|c|}{ Carbon dioxide combining power } \\
\hline $\begin{array}{l}1 \\
7 \\
8\end{array}$ & $\begin{array}{l}\text { February 25, } 1941 \\
\text { June } 20,1941 \\
\text { July } 1,1941 \\
\text { April 18, } 1941 \\
\text { April 25, 1941 } \\
\text { April 30, } 1941 \\
\text { July } 18,1941\end{array}$ & $\begin{array}{l}0.6 \\
0.02 \\
0.5 \\
0.0006 \\
0.006 \\
0.03 \\
0.1\end{array}$ & $\begin{array}{l}46.6 \\
55.3 \\
46.6 \\
46.6 \\
44.7 \\
44.7 \\
46.6\end{array}$ & & & $\begin{array}{l}\text { O2 per } \\
44.7 \\
33.4 \\
40.9 \\
46.6 \\
45.7\end{array}$ & $\begin{array}{l}\text { c. of ple } \\
44.8\end{array}$ & & & $\begin{array}{l}39.0 \\
44.7 \\
37.2 \\
37.2 \\
39.0 \\
40.9 \\
44.7\end{array}$ \\
\hline
\end{tabular}


the median basilic vein, on several patients, which yielded values with variations within experimental error.

c. Hemoglobin and erythrocytes. The erythrocytes and hemoglobin failed to show any definite change following a single injection, but after repeated doses, however, several of the patients showed a definite reduction in both hemoglobin and red cells. Such changes have been described in typhoid fever by Holmes (15). In addition to the other determinations, the volume of packed cells was followed throughout the paroxysm in order to detect any changes due to fluid loss produced by the perspiration and vomiting. No significant alterations were observed. However, patients were allowed to partake of fluids at will, though the fluid intake was usually minimal because of the nausea so frequently present. The sedimentation rate of the erythrocytes was followed during the period of observation of the patients and particularly during the administration of the antigen. Following the initial administration of antigen, the sedimentation rate rose appreciably. This elevation was maintained and often increased by subsequent administration. Starting with an elevated rate, little or no variation was noted in the rate, by hourly determinations during the paroxysm. Data typical of the series are presented in Table IV.

\section{Chemical changes in the blood}

In summarizing the changes in the chemical constituents of the blood, it may be said that there was a slight to moderate immediate reduction in the values of blood glucose and a subsequent rise in 5 to 7 hours to levels above the initial values, in most cases. The patients showed some reduction in the values for blood chlorides and in the carbon dioxide combining power of the plasma. These data are summarized in Table V. There were no significant variations in the values for total protein, urea nitrogen, or creatinine.

\section{Immunologic responses to the injections}

$\mathrm{O}$ agglutinins were demonstrable as early as the 5th day after the initial injection, and reached their maximum titer at about the end of the 2nd week (Figure 2). This level was approximately

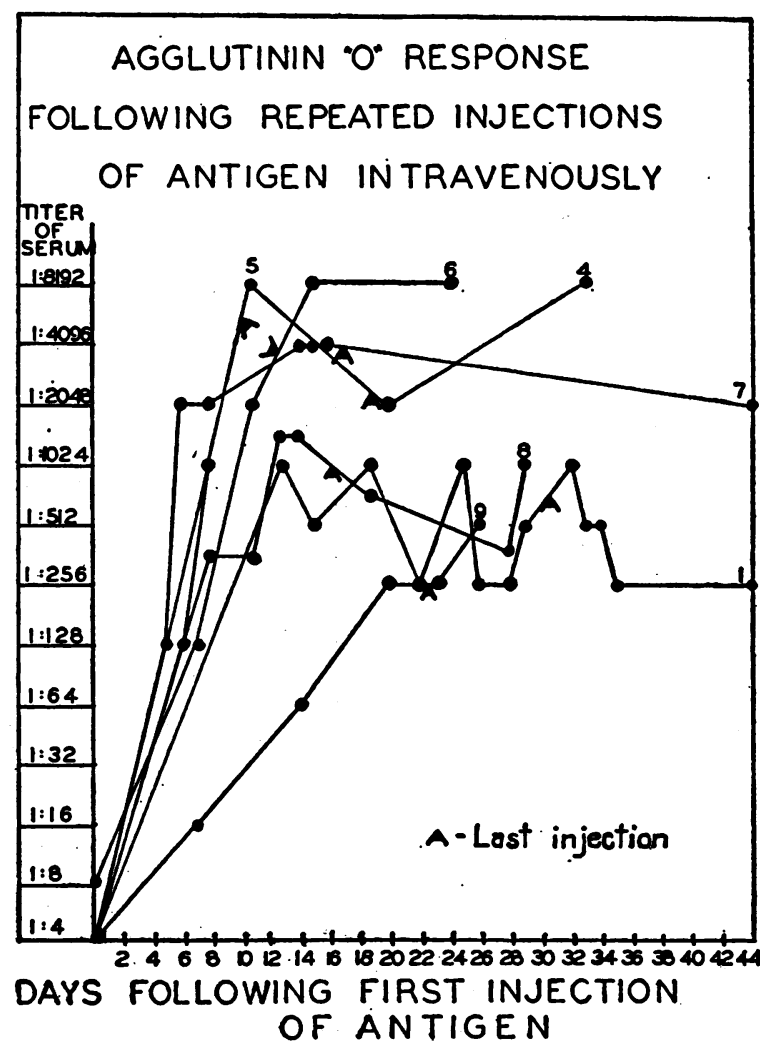

Fig. 2. Agglutinin Titers in Patients Following the INJECTION OF ANTIGEN

maintained for considerable periods of time, as demonstrated in patients 1,6 , and 7 . In several instances in which the sera of patients were retested 6 weeks after the last injection of antigen, only a small decrease in the titer was noted. Vi agglutinins were present in most instances. $\mathrm{H}$ agglutinins were not detected.

The precipitin titers were performed at less frequent intervals but bore evidence to a good antigenic response by attaining values which ranged from $1: 10,000$ and $1: 100,000$ dilutions of antigen (Table VI).

Since previous experiments (5) had indicated that the intravenous injection of the antigen resulted in the formation of bactericidal antibodies for $E$. typhosa, the sera of patients were tested for their presence. Progressive development of high titers was demonstrated (Table VI). Figure 3 presents a correlation of these various antibody titrations with the dosage of antigen administered in case 7. Table VI summarizes antibody titers and total dosage of antigen administered. 


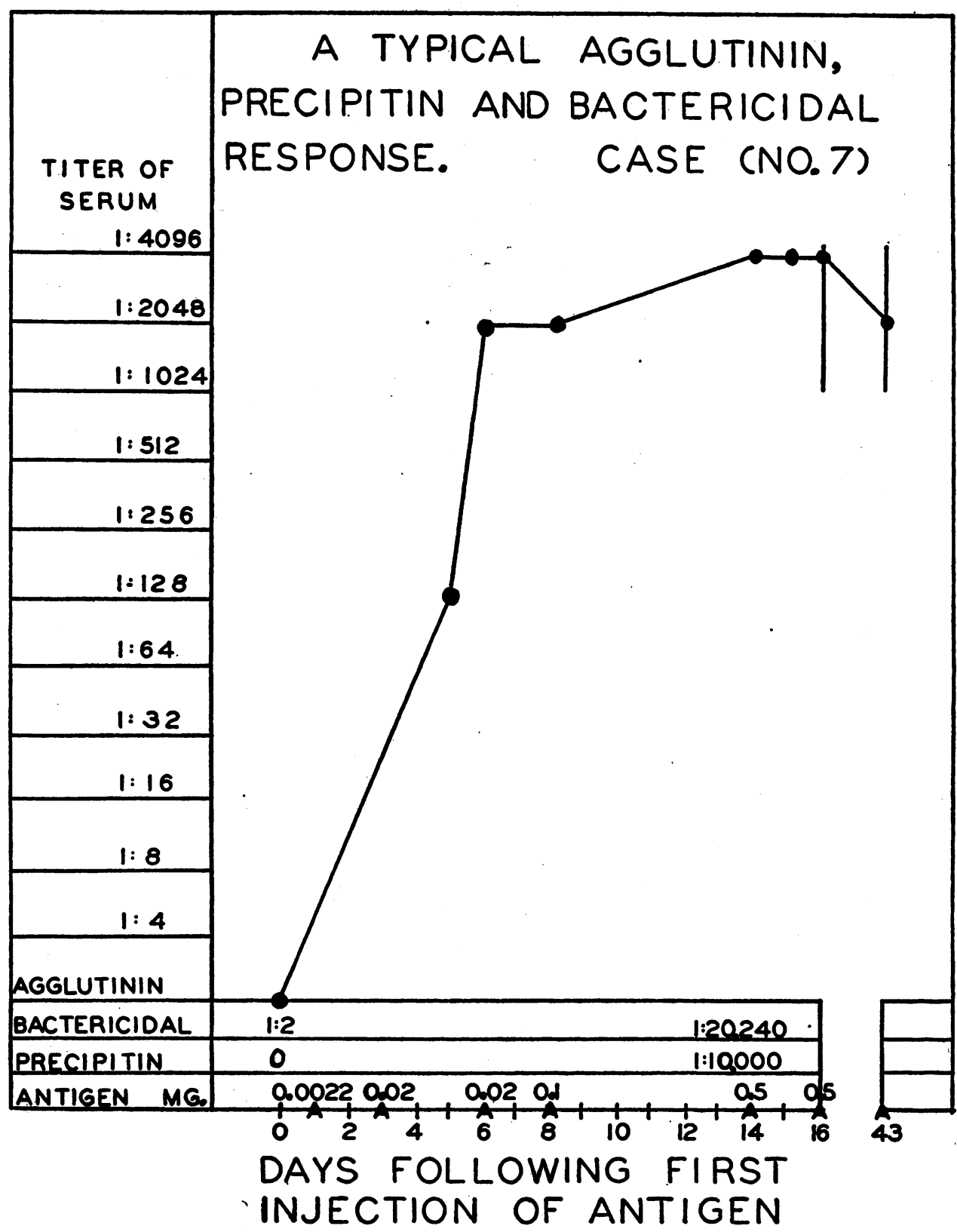

Fig. 3. Antibody Titers. Patient 7

DISCUSSION

The evidence presented demonstrates that the effects produced by the antigenic material, on intravenous administration to patients, are the same as those previously reported following its administration to animals (4), in respect to the development of fever, leukopenia, and immunologic responses as measured by the production of agglutinins, precipitins, and bactericidal antibodies.
The reactions to the injection of this antigen are similar to those produced in patients by the intravenous injection of typhoid bacilli $(16,17)$. The effective dose in man proved to be considerably smaller than in animals, since $0.0001 \mathrm{mgm}$. gave an initial response, whereas 0.01 to $0.05 \mathrm{mgm}$. represented the usual, initial, effective dose for rabbits (4). The capacity of the material to induce these reactions and the demonstration that 
TABLE VI

Bactericidal, precipitin, and agglutinin titers, following a series of injections of the antigen

\begin{tabular}{|c|c|c|c|c|c|c|c|c|c|}
\hline \multirow{3}{*}{ Patient } & \multirow{3}{*}{$\begin{array}{l}\text { Date blood } \\
\text { was taken }\end{array}$} & \multirow{3}{*}{$\mid \begin{array}{c}\frac{\text { Bactericidal }}{\text { titer }} \\
\begin{array}{c}\text { Dilution of } \\
\text { serum }\end{array}\end{array}$} & \multirow{3}{*}{\begin{tabular}{|c|}
$\begin{array}{c}\text { Precipitin } \\
\text { titer }\end{array}$ \\
$\begin{array}{c}\text { Dilution of } \\
\text { antigen }\end{array}$ \\
\end{tabular}} & \multirow{2}{*}{\multicolumn{2}{|c|}{ 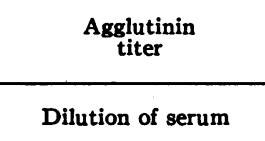 }} & \multirow{3}{*}{$\begin{array}{l}\text { Days be- } \\
\text { tween 1st } \\
\text { injection } \\
\text { and 1st } \\
\text { titer }\end{array}$} & \multirow{3}{*}{$\begin{array}{l}\text { Days be- } \\
\text { tween 1st } \\
\text { injection } \\
\text { and 2nd } \\
\text { titer }\end{array}$} & \multicolumn{2}{|c|}{$\begin{array}{l}\text { Accumulative dose } \\
\text { of antigen at }\end{array}$} \\
\hline & & & & & & & & \multirow{2}{*}{ 1st titer } & \multirow{2}{*}{ 2nd titer } \\
\hline & & & & 0 & $\mathrm{Vi}$ & & & & \\
\hline 1 & $\begin{array}{l}\text { January } 30,1941 \\
\text { February } 25,1941\end{array}$ & $\begin{array}{l}1: 40 \\
1: 20480\end{array}$ & $\begin{array}{l}1: 100 \\
1: 100000\end{array}$ & $\begin{array}{l}1: 4 \\
1: 2048\end{array}$ & $\begin{array}{l}0 \\
1: 16\end{array}$ & 2 & 27 & $\begin{array}{c}m g m . \\
0.0006\end{array}$ & $\begin{array}{c}\text { mgm. } \\
1.6316\end{array}$ \\
\hline 2 & $\begin{array}{l}\text { November 6, } 1940 \\
\text { April 28, } 1941\end{array}$ & $\begin{array}{l}1: 20480 \\
1: 5120\end{array}$ & $\begin{array}{ll}1: 100000 \\
1: 10000\end{array}$ & $\begin{array}{l}1: 4096 \\
1: 1024\end{array}$ & $\begin{array}{l}1: 8 \\
1: 2\end{array}$ & 23 & 195 & 0.8076 & 0.8076 \\
\hline 3 & $\begin{array}{l}\text { December 9, } 1940 \\
\text { January 18, } 1941\end{array}$ & $\begin{array}{l}1: 64 \\
1: 1024\end{array}$ & $\begin{array}{l}1: 10 \\
1: 10000\end{array}$ & $\begin{array}{l}1: 2 \\
1: 512\end{array}$ & $\begin{array}{l}0 \\
1: 16\end{array}$ & 0 & 40 & 0.0000 & 0.6665 \\
\hline 4 & $\begin{array}{l}\text { November 6, } 1940 \\
\text { December 9, } 1940\end{array}$ & $\begin{array}{l}0 \\
1: 10240\end{array}$ & $\begin{array}{l}0 \\
1: 100000\end{array}$ & $\begin{array}{l}0 \\
1: 4096\end{array}$ & $\begin{array}{l}0 \\
1: 8\end{array}$ & 0 & 33 & 0.0000 & 0.9033 \\
\hline 5 & $\begin{array}{l}\text { February 6, } 1941 \\
\text { March 4, } 1941\end{array}$ & $\begin{array}{l}1: 128 \\
1: 40960\end{array}$ & $\begin{array}{l}1: 10 \\
1: 100000\end{array}$ & $\begin{array}{l}1: 20 \\
1: 8192\end{array}$ & $\begin{array}{l}0 \\
1: 16\end{array}$ & 2 & 28 & 0.0002 & 0.0682 \\
\hline 7 & $\begin{array}{l}\text { June } 20,1941 \\
\text { July } 3,1941\end{array}$ & $\begin{array}{l}1: 2 \\
1: 20480\end{array}$ & $\begin{array}{l}0 \\
1: 100000\end{array}$ & $\begin{array}{l}0 \\
1: 4096\end{array}$ & $\begin{array}{l}0 \\
1: 64\end{array}$ & 2 & 15 & 0.0022 & 1.1122 \\
\hline 8 & $\begin{array}{l}\text { April 18, } 1941 \\
\text { May 29, } 1941\end{array}$ & $\begin{array}{l}1: 128 \\
1: 20480\end{array}$ & $\begin{array}{l}1: 10 \\
1: 100000\end{array}$ & $\begin{array}{l}0 \\
1: 1024\end{array}$ & $\begin{array}{l}0 \\
0\end{array}$ & 1 & 42 & 0.0002 & 0.0876 \\
\hline 9 & $\begin{array}{l}\text { June } 25,1941 \\
\text { July } 21,1941\end{array}$ & $\begin{array}{l}1: 160 \\
1: 10240\end{array}$ & $\begin{array}{l}1: 100 \\
1: 100000\end{array}$ & $\begin{array}{l}1: 8 \\
1: 2048\end{array}$ & $\begin{array}{l}0 \\
0\end{array}$ & 0 & 26 & 0.0005 & 0.4530 \\
\hline
\end{tabular}

it is released during the growth of the typhoid bacillus again suggests that it might be related to the development of certain clinical manifestations of typhoid fever in patients, as was earlier postulated (4) on the basis of the animal experiments.

The most striking changes noted in the studies of the blood were the alterations in the total and differential leukocyte counts. The leukopenia which developed in patients following adequate dosage was due almost entirely to a decrease in the number of polymorphonuclear leukocytes (Figure 1). The subsequent return of the leukocyte count to normal levels and the later development of a leukocytosis was due largely to a release of young polymorphonuclear leukocytes from the bone marrow.

The mechanism of the production of the leukopenia following the intravenous injection of typhoid bacilli in animals and man is a controversial matter. The conflicting theories and their supporting evidence have been summarized by Garrey and Bryan (18) who discuss the possibility that the leukocytes are trapped in the vascular bed of internal organs, as opposed to the view that the leukopenia may be due to the destruction of these cells. The results of several investigations (18) give evidence for such accumulation of polymorphonuclear leukocytes within the vessels of the lung, spleen, and other organs of animals, following the intravenous injection of typhoid bacilli or toxic filtrates derived from cultures of $E$. $t y$ phosa. These observations are in contrast to the earlier findings of Pepper and Miller (19) who failed to show such accumulations. Pepper and Miller also stated that Arneth differential counts made during the leukocytosis, which superseded the leukopenia, showed such a great increase in the numbers of young polymorphonuclear leukocytes as to suggest that at least part of the mature leukocytes had not returned to the circulation. A like situation was reported in the experiments of Cowie and Calhoun (16) and Perera (17) who studied the changes in the leukocyte count following the intravenous injection of typhoid vaccine into patients. Both of these authors report a "shift to the left" in the differential polymorphonuclear leukocyte counts during the leukocytosis, which suggests that the leukocytosis is due to a 
release of young cells from the bone marrow. The striking increase in the numbers of stab forms of polymorphonuclear leukocytes, demonstrated in these experiments at a time when the leukocyte count had increased only to normal levels, indicates that this return to normal was not due to a release of adult cells that had been trapped in internal organs, but rather to an increased activity of the bone marrow, comparable to that previously described in animals that received injections of the antigenic material (7). Moreover, the recent experiments of Dennis and Senekjian (20), which show that a similar antigenic material isolated from cultures of $E$. typhosa has a selective destructive action on polymorphonuclear leukocytes when added to human blood in vitro, further support the hypothesis that these substances produce the leukopenia, at least in part, by the destruction of polymorphonuclear leukocytes.

The blood picture following the injection of this antigenic material is similar to that described by Schilling (14) in patients with typhoid fever, with its neutropenia, increased number of stab cells, and absence of eosinophiles.

The failure of the injection of this material to affect appreciably most of the chemical constituents of the blood is in agreement with the data of Perera (17). The tendency for the blood sugar to rise is similar to the observations by Delafield (21) that somatic antigens of the Salmonella group produce a hyperglycemia in animals.

The immunologic responses of the patients to the injection of the antigen reveal that it has high potency as an antigenic agent and suggests that it might be of use in immunization. Studies are now in progress on a group of volunteers to elucidate this property, and preliminary results (6) indicate that the material will prove of value. Again, as in the earlier experiments utilizing rabbits (4), it is suggested that a high titer of circulating antibody is not correlated with resistance to the toxic effect of the antigen, as larger doses produced toxic effects in the presence of very high antibody titers (Table I). A certain degree of resistance to the toxicity of the antigen developed following consecutive administration but injections made several months later, as in the case of patient 6 , produced febrile reactions of considerable intensity at a time when the blood serum showed a significant titer of agglutinins. The significance of this observation that circulating antibody cannot be correlated with the resistance to toxicity has been previously discussed in detail with regard to the experiments utilizing rabbits (4). These observations may, in part at least, account for the seemingly paradoxical fact that symptoms of toxemia in typhoid fever persist in the presence of circulating antibody whether this be naturally present or introduced through the administration of antiserum.

\section{SUMMARY}

1. An antigenic material prepared from cultures of $E$. typhosa grown in a synthetic medium produced chills, fever, perspiration, and muscular aching, following the intravenous injection of minute amounts in man. The severity of the reaction was dependent on the amount of material administered. With consecutive injections, larger doses were required to produce similar systemic reactions, indicating a tolerance to its toxicity.

2. The injection of the material was followed by the development of a leukopenia which was almost entirely due to a decrease in the numbers of polymorphonuclear leukocytes in the capillary blood. This leukopenia was followed by a return of the leukocytes to normal levels, and by a subsequent leukocytosis in which the number of stab cells was markedly increased.

3. No marked changes were observed in determinations of total protein, urea nitrogen, creatinine, chloride, glucose, and carbon dioxide combining power of the blood, during and in the several hours following the reaction. The sedimentation rate of the erythrocytes rose after injections.

4. Serological tests, following repeated injections, revealed the production of high titers of agglutinins, precipitins, and bactericidal antibodies, which then remained at high levels for considerable periods of time. The titer of the circulating antibody did not seem to be closely related to the development of tolerance to the toxicity of the antigen.

5. The possible relationship of these findings to certain of the manifestations of typhoid fever are discussed.

The authors are grateful for the advice and constructive criticism of Dr. John F. Enders of the Department of Bacteriology of the Harvard Medical School. 


\section{BIBLIOGRAPHY}

1. Boivin, A., Mesrobeanu, I., and Mesrobeanu, L., Technique pour la préparation des polysaccharides microbiens spécifiques. Compt. rend. Soc. de Biol., 1933, 113, 490.

2. Raistrick, H., and Topley, W. W. C., Immunizing fractions isolated from Bact. aertrycke. Brit. J. Exper. Path., 1934, 15, 113.

3. Morgan, $H$. R., Preparation of an antigenic material inducing leucopenia from Eberthella typhosa cultured in a synthetic medium. Proc. Soc. Exper. Biol. and Med., 1940, 43, 529.

4. Morgan, H. R., Immunologic properties of an antigenic material isolated from Eberthella typhosa. J. Immunol., 1941, 41, 161.

5. Cundiff, R. J., and Morgan, H. R., The inhibition of the bactericidal power of human and animal sera by antigenic substances obtained from organisms of the typhoid-Salmonella group. J. Immunol., 1941, 42, 361.

6. Morgan, H. R. (Unpublished experiments.)

7. Morgan, H. R. (In press.)

8. Kagan, B. M., A simple method for the estimation of total protein content of the plasma and serum. II. The estimation of total protein content of human plasma and serum by the use of the falling drop method. J. Clin. Invest., 1938, 17, 373.

9. Karr, W. G., A method for the determination of blood urea nitrogen. J. Lab. and Clin. Med., 1924, 9, 329.

10. Folin, O., Laboratory Manual of Biological Chemistry. D. Appleton-Century Co., Inc., New York, 1934.
11. Folin, O., Two revised copper methods for blood sugar determinations. J. Biol. Chem., 1929, 82, 83.

12. Whitehorn, J. C., Simplified method for the determination of chlorides in blood or plasma. J. Biol. Chem., 1921, 45, 449.

13. Van Slyke, D. D., and Cullen, G. E., Studies of acidosis. I. The bicarbonate concentration of the blood plasma; its significance and its determination as a measure of acidosis. J. Biol. Chem., 1917, 30, 289. II. A method for the determination of carbon dioxide and carbonates in solution. Ibid., 347.

14. Schilling, V., The Blood and Its Clinical Significance. C. V. Mosby Co., St. Louis, 1929.

15. Holmes, W. H., Bacillary and Rickettsial Infections. The Macmillan Co., New York, 1940.

16. Cowie, D. M., and Calhoun, H., Nonspecific therapy in arthritis and infections. Arch. Int. Med., 1919, 23, 69.

17. Perera, G. A., Clinical and physiologic characteristics of chill. Arch. Int. Med., 1941, 68, 241.

18. Garrey, W. E., and Bryan, W. R., Variations in white blood cell counts. Physiol. Rev., 1935, 15, 597.

19. Pepper, O. H., and Miller, T. G., The relation of allantoin excretion to leukopenia and leucocytosis in rabbits. J. Infect. Dis., 1916, 19, 694.

20. Dennis, E. W., and Senekjian, H., A leucocidal toxin extracted from typhoid bacilli. Am. J. Hyg. (sect. B), 1939, 30, 103.

21. Delafield, M. E., Blood sugar changes and toxic effects produced in rabbits by certain fractions derived from $B$. aertrycke. Brit. J. Exper. Path., 1934, 15, 130. 